\title{
Confirmation of HCV viremia using HCV RNA and core antigen testing on dried blood spot in HIV infected peoples who inject drugs in Vietnam
}

Truong Tam Nguyen ${ }^{1,2^{*}}$ (D) Véronique Lemee ${ }^{3}$, Karine Bollore ${ }^{2}$, Hai Vinh Vu ${ }^{4}$, Karine Lacombe ${ }^{5}$, Xuan Lien Truong Thi ${ }^{6}$, Que Anh Luong ${ }^{6}$, Charline Dubos ${ }^{3}$, Jean-Christophe Plantier ${ }^{3}$, Huong Duong Thi $^{7}$, Didier Laureillard ${ }^{8}$, Maud Lemoine ${ }^{9}$ and Edouard Tuaillon ${ }^{2}$

\begin{abstract}
Background: Nucleic acid tests performed on blood samples collected on Dried Blood Spot (DBS) and detection of $\mathrm{HCV}$ core antigen ( $\mathrm{HCV}$ cAg) are two approaches that may facilitate access to HCV diagnosis in low and middle incomes countries. In this study we evaluate HCV RNA and HCV antigen testing on DBS in HIV/HCV co-infected peoples who inject drugs in Vietnam.

Method: One hundred and four HIV/HCV seropositive patients managed in outpatient care at the Haiphong Viet Tiep hospital were included in this study from February to March, 2014 (ANRS 12262 study).

Results: Eighty-six subjects were tested positive for HCV RNA in serum, median (IQR): $6.9 \log _{10} \mathrm{IU} / \mathrm{ml}\left(5.6-7.4 \log _{10}\right.$ IU/ml). Genotypes consisted of 57 G1 (69\%), 3 G3 (4\%), and 22 G6 (27\%). HCV RNA was detected on DBS specimens in 79 out 86 subjects with chronic hepatitis C (sensitivity 92.5\%; 95\% Cl: 85.1-96.9\%). HCV RNA level on DBS and serum was moderately correlated $(r=0.24 ; p=0.05)$ suggesting a degradation of HCV RNA due to transportation and storage conditions. HCVcAg was detected in 75/86 dB specimens (sensitivity: 87.2\%; 95\% Cl: 78.3-93.4\%), with a strong positive relationship between DBS HCVCAg and serum HCV RNA levels $(r=0.80 ; P<0.0001)$.

Conclusions: Quantification of HCVCAg on DBS appears to benefit from substantial stability under prolonged storage conditions but with a lower analytical sensitivity compared to DBS HCV RNA testing. Detection of HCV RNA on DBS is an interesting approach for confirming viral replication in HCV seropositive persons but the impact of pre-analytical conditions on the integrity of HCV RNA needs to be controlled.
\end{abstract}

Keywords: Hepatitis C virus (HCV), Human immunodeficiency virus (HIV), HCV core antigen, HCV RNA, Vietnam

\section{Background}

Decisive breakthrough was recently achieved in hepatitis $\mathrm{C}$ virus $(\mathrm{HCV})$ antiviral therapy but the limited access to reliable and low-cost HCV diagnosis tools is a key barrier in the global fight against $\mathrm{HCV}$ epidemic [1]. The World health organization (WHO) has recently incorporated HCV elimination in its 2030 agenda and has called

\footnotetext{
* Correspondence: ntruongtam@yahoo.fr

1 University of Medicine Pham Ngoc Thach, Ho Chi Minh City, Vietnam

${ }^{2}$ Pathogenesis and Control of Chronic Infections, INSERM, Université de Montpellier, CHU Montpellier, Montpellier, France

Full list of author information is available at the end of the article
}

for a $90 \%$ decrease in $\mathrm{HCV}$ incidence and $65 \%$ of HCV-related mortality [2]. In order to achieve these objectives, it is critical to simplify HCV testing in particular in high risk populations. However, $\mathrm{HCV}$ infection is frequently undiagnosed because the course of the disease is generally asymptomatic until end stage of liver disease. In low- and middle-income settings, where the burden of $\mathrm{HCV}$ is high, it is estimated that more than $95 \%$ of people are unaware of their HCV status [3, 4]. Screening for $\mathrm{HCV}$ infection is currently based on the detection of anti-HCV antibodies (HCVAb) followed by HCV RNA detection to confirm active infection. Rapid diagnosis

(c) The Author(s). 2018 Open Access This article is distributed under the terms of the Creative Commons Attribution 4.0 International License (http://creativecommons.org/licenses/by/4.0/), which permits unrestricted use, distribution, and 
test format provides a valuable alternative to laboratory tests for the scaling-up of HCV testing [4]. Over the last years whilst simple rapid diagnosis tests for HCVAb detection have been developed with two manufacturers fulfilling requirements for the WHO prequalification $[5,6]$, access to molecular assays is still limited in resource-limited countries. Poor laboratory capacities and logistical difficulties represent key barriers for the scaling testing and the treatment, particularly in rural areas and difficult to reach populations.

Serological methods assessing $\mathrm{HCV}$ core antigen ( $\mathrm{HCVcAg}$ ) can be surrogate assays to nucleic acid tests for detection of $\mathrm{HCV}$ viremia. $\mathrm{HCV}$ cAg detection can be less costly than PCR and may have a clinical utility in low and middle income countries [7]. Conditional recommendation has recently been published by WHO to consider the use of $\mathrm{HCVcAg}$ assays as a possible method to confirm HCV infection [4]. In this first global guidelines directed at low- and middle-incomes countries, the capillary sampling on blotting paper (DBS) is also considered as an easily transportable and simple alternative to peripheral venous sampling for confirmation of $\mathrm{HCV}$ infection based on RNA detection [1,4]. In rural and resource-limited areas, DBS offer a simple transportable alternative to peripheral venous sampling and represents an appealing method for scaling up testing.

In Vietnam, the presence of anti-HCV antibodies has been reported between 1 to $6 \%$ of the general population and is dramatically higher (up to $90 \%$ ) in people who inject drugs $[8,9]$. The Vietnamese Ministry of Health has recently developed a national $\mathrm{HCV}$ guidance upon the release of the first WHO Guidelines on HCV care and treatment [10]. We previously reported a high proportion of advanced liver fibrosis among HIV-HCV co-infected peoples who inject drugs in Haiphong, Northern Vietnam [11]. In this study we evaluate the performance of $\mathrm{HCV}$ RNA and HCV antigen detection on DBS collected in Haiphong Viet Tiep Hospital and compared to serum PCR using open polyvalent PCR platform.

\section{Patients and methods}

\section{Study population}

The source population was HIV-infected outpatients reporting past injection or ongoing drug use who also participated in a cross-sectional study conducted at the Viet Tiep hospital in Haiphong between February and March 2014 (ANRS 12262). Eligibility criteria were: age over 18 years, positivity for anti-HCV antibodies and HCV RNA, HCV treatment-naïve status, ART initiated for more than 6 months, CD4+ T cells count over 200/ $\mathrm{mm}^{3}$. Patients tested positive for $\mathrm{HCV}$ antibodies using both a rapid test (SD Bioline anti-HCV rapid test, Standard Diagnostics Inc., Korea) and laboratory test (Phamatech anti HCV EIA kit, USA) were prospectively enrolled after providing written consents. Sample size calculation was performed based on an expected sensitivity of 0.85 (95\% acceptable lower CI: 0.70) using $\mathrm{HCV}$ cAg on DBS for identification of $\mathrm{HCV}$ chronic hepatitis, to control the design accuracy [12]. HCV RNA quantification and $\mathrm{HCV}$ genotyping were assessed as previously described [10]. Briefly, HCV RNA in serum was extracted using the MagNa Pure 96 system and quantified using a CE marked HCV kit (HCV Real-time Quant, Sacace Biotechnologies, Italy) on LightCycler 480 instrument (Roche, USA). HCV genotyping was performed for samples with HCV RNA level above 1000 copies/mL as previously described. HCV subtypes were identified using the Los Alamos Hepatitis $C$ sequence (www.hcv.lanl.gov). Blood samples from $\mathrm{HCV}$ infected outpatients followed in the Montpellier University hospital and having provided informed consent were used for the validation of PCR and $\mathrm{HCVCAg}$ methods on DBS specimens (DC-2008-417). HCV RNA levels of $\mathrm{HCV}$ samples collected in France were quantified using the COBAS $^{\ominus}$ AmpliPrep/COBAS ${ }^{\circ}$ TaqMan $^{\circ}$ V2.0 assay (Roche), and genotypes were determined using the $\mathrm{HCV}$ Versant Genotype 2.0 assay (LiPA) (Siemens Healthcare Diagnostics, Tarrytown, NY). HCV genotypes consists of G1 $(n=18), \mathrm{G} 2(n=2), \mathrm{G} 3(n=9), \mathrm{G} 4(n=8), \mathrm{G} 5(n=1)$. The study protocol and written informed consent form were approved by the Ethic Committee of the Viet Tiep Hospital and the Institutional Review Board (IRB) of the Haiphong Medical Services ( $n^{\circ}$ 01BVVT/HDKH). Then, the written informed consent was obtained from all participants before blood sampling.

\section{DBS specimen preparation}

Fifty microliters of venous whole-blood collected in ethylene diamine tetraacetic acid tube was spotted onto the filter paper card (Whatman 903; GE Healthcare Europe, Freiburg, Germany). The filter paper was dried at ambient temperature, stored in an individual sealed plastic bag with a desiccant package at $-20^{\circ} \mathrm{C}$. DBS samples collected from the Montpellier University Hospitals were stored at $-20^{\circ} \mathrm{C}$ until used. Samples from the Viet Tiep hospital in Haiphong were defrosted and transported at ambient temperature during $72 \mathrm{~h}$, and stored again at $20^{\circ} \mathrm{C}$ for a mean duration of 18 months until HCV RNA and $\mathrm{HCV}$ Ag testing.

\section{HCV RNA testing on DBS specimens}

HCV RNA were quantified in DBS using the HCV Generic assay (Generic HIV Viral Load, Biocentric, France) with a detection limit of $80 \mathrm{IU} / \mathrm{mL}$ using $0.2 \mathrm{~mL}$ of serum. For DBS elution, 2 punched disks with a $6 \mathrm{~mm}$ diameter was eluted into $200 \mu \mathrm{l}$ of elution buffer (PBS, BSA $10 \%$, Tween $0,05 \%$ ) at $4{ }^{\circ} \mathrm{C}$ with gentle agitation for $1 \mathrm{~h}$. The nucleic acid extraction was done using $140 \mu \mathrm{L}$ 
of DBS eluate on the Qiacube apparatus, and the amplification - using the LigthCycler 480 thermocycler (Roche). An estimated input plasma volume of $2-3 \mu \mathrm{L}$ per PCR were used instead of $40 \mu \mathrm{L}$ per PCR on serum. Then, DBS samples collected in the Haiphong Viet Tiep hospital were tested for HCV RNA in the Montpellier University Hospital using the same procedure.

\section{HCVcAg testing on DBS specimens}

$\mathrm{HCV}$ cAg testing was performed using an automated chemiluminescent microparticle immunoassay (Architect $\mathrm{HCV}$ antigen assay; Abbott Diagnostics, Chicago, Illinois) as previously described [13]. Briefly, a punched disk of $6 \mathrm{~mm}$ diameter was eluted into $1 \mathrm{~mL}$ of $0.05 \%$ Tween $20 \mathrm{PBS}$ at $4{ }^{\circ} \mathrm{C}$ with gentle agitation for $60 \mathrm{~min}$. A total of $20 \mu \mathrm{L}$ of DBS supernatant was used for the assay.

\section{Statistical analysis}

Continuous variables were described as median and inter-quartile range (IQR). HCV RNA concentrations were converted to $\log _{10}$ values before performing statistical analysis. Relationships between quantitative variables were studied by means of Pearson correlation. Bland-Altman bias plots were used to assess the differences between the different assays and clinical samples. For each plot, mean bias and 95\% confidence interval ( $95 \% \mathrm{CI}$ ) of the bias were calculated and the mean biases were compared using Student's t-test. The agreement between the detection of DBS HCV RNA and DBS $\mathrm{HCV}$ cAg was analyzed using Cohen's kappa test. All statistical analyses were done with MS Excel and Graphpad Prism 6.0 (GraphPad Software, Inc., San Diego, CA).

\section{Results}

\section{Comparison of HCV RNA quantification on serum and} DBS specimens

HCV RNA values on DBS specimens were compared to serum HCV RNA values quantified in matched serum samples collected in $37 \mathrm{HCV}$-infected patients followed in the Montpellier University Hospital, France. HCV RNA were detected in all DBS samples. The median IQR HCV RNA were $5.5 \log \mathrm{IU} / \mathrm{mL}$ on serum and 3.8 $\log \mathrm{IU} / \mathrm{mL}$ on DBS elution buffer. We observed a good correlation between DBS using the Biocentric assay and serum HCV RNA using the Roche assay (Fig. 1a) $(r=$ 0.9488; $P<0.0001$ ). The mean difference (bias \pm SD) between the results on DBS and the reference HCV RNA level was $1.391 \pm 0.32 \log \mathrm{IU} / \mathrm{mL}$. Bland-Altman analysis shown that 36 (97\%) results were seated within the 95\% confidence interval (Fig. 1b). The limit of detection (LOD) for HCV RNA on DBS was estimated at $3000 \mathrm{IU} /$ $\mathrm{mL}$ (data not shown).

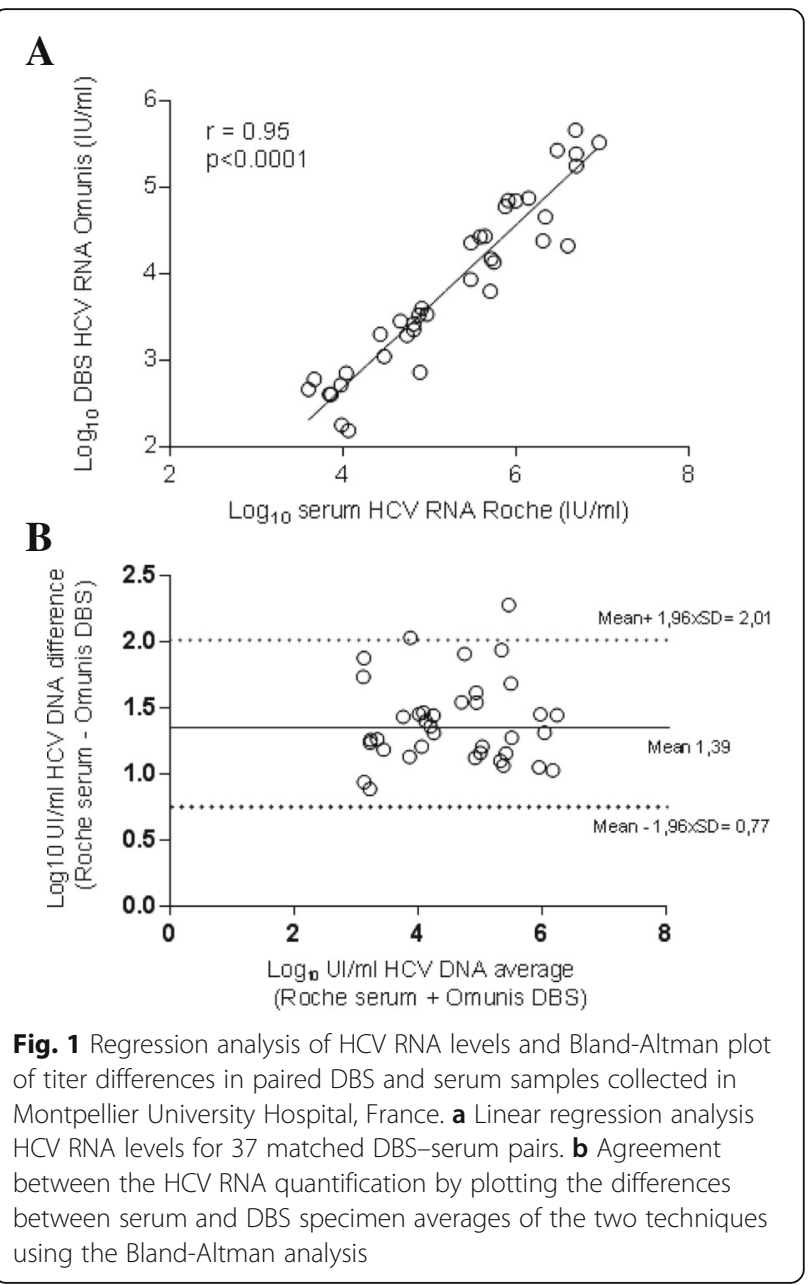

HCV RNA detection and quantification on DBS specimens collected from HIV/HCV co-infected patients from Viet Tiep hospital, Hai Phong, Vietnam

One hundred and four patients were tested positive for HCV antibodies. DBS samples were available for 101 of them. Patients' characteristics were summarized in Table 1. Eighty-six subjects (85\%) were tested positive for $\mathrm{HCV}$ RNA in serum, median (IQR): $6.9 \log 10 \mathrm{IU} / \mathrm{mL}(5.6-7.4$ $\left.\log _{10} \mathrm{IU} / \mathrm{mL}\right)$. Genotypes were determined in $82 / 86$ samples (95\%) samples: G1 $(n=57), \mathrm{G} 3(n=3), \mathrm{G} 6(n=22)$. HCV RNA was detected in $79 / 86 \mathrm{~dB}$ samples (sensitivity 92.5\%; 95\% CI: 85.1-96.9\%; negative predictive value 68.2\%; 95\% CI: 51.2-81.4\%). Fifteen patients (15\%) were tested positive for anti-HCV antibodies using rapid diagnosis test and laboratory method but were found negative for $\mathrm{HCV}$ RNA. None of above mentioned samples were found positive for HCV RNA on DBS (specificity: 100\%; 95\% CI: 78.2-100\%; positive predictive value: $100 \%$ ). Among seven specimens collected from viremic patients but tested negative for HCV RNA on DBS, the viral load in the matching serum ranged from 711 to $339,000 \mathrm{IU} / \mathrm{mL}$ (median 121,000 IU/mL; IQR: 10,600 to 261,000). Four DBS were 
Table 1 Clinical characteristics of study participants

\begin{tabular}{ll}
\hline Characteristics & \\
Patients (total) & 101 \\
Sex Male/Female & $97 / 4$ \\
Age years (IQR) & $34.3(31.2-40.3)$ \\
IV drug use (n) & $72(69.2 \%)$ \\
HCV and HIV diseases characteristics & \\
Fibrosis > F2 (n) & $24(23 \%)$ \\
CD4 T cell count ( $\mu l$, IQR) & $504(357-624)$ \\
Nadir of CD4 T cells ( $\mu l$, IQR) & $82(35-173)$ \\
2NRTI and NNRTI & $97(96 \%)$ \\
2NRTI and IP & $5(4 \%)$ \\
HIV RNA < 50 copies/ml (n) & $97(96 \%)$ \\
\hline
\end{tabular}

Median and interquartile range (IQR) were used for continuous variables $S D$ Standard deviation, NRTI Nucleosidique Reverse Transcriptase Inhibitors, NNRTI Non Nucleosidique Reverse Transcriptase Inhibitors

positive for HCV RNA but with concentration seated below the lower limit of detection of the PCR assay $(80 \mathrm{IU} / \mathrm{mL})$, whereas in the matching serum the $\mathrm{HCV}$ RNA ranged from 35,500 to 32,600,000 IU/mL (median 16,360,000 IU/ mL; interquartile range: 856,625 to $31,800,000)$. HCV RNA was successfully quantified in 75/86 samples (87\%), (median HCV RNA: $1840 \mathrm{IU} / \mathrm{mL}$ of DBS elution buffer, IQR 957 to 4060). We observed a low correlation between DBS and serum HCV RNA measurements (Fig. 2a) $(r=0.24 ; p=$ 0.0135). Mean difference between HCV RNA values obtained with DBS vs. serum on Bland-Altman plot was 2.9 $\log \mathrm{IU} / \mathrm{mL}$, with limits of agreement (mean difference \pm 2 standard deviation) $\pm 3.28 . \log \mathrm{IU} / \mathrm{mL}$ (Fig. 2b). All the values were within the $95 \%$ confidence interval.

\section{HCVcAg detection and quantification on DBS specimens} collected from HIV/HCV co-infected patients from Viet Tiep hospital, Hai Phong, Vietnam

DBS were tested for the presence of HCVcAg using the Architect $\mathrm{HCV}$ antigen assay. HCVcAg was detected on DBS in 75/86 (sensitivity: 87.2\%; 95\% CI: 78.3-93.4\%; negative predictive value: $57.7 \%$; $95 \% \mathrm{CI}$ : 43.9-70.3\%). All serum samples tested negative for HCV RNA were undetectable for $\mathrm{HCVCAg}$ in matched DBS samples (specificity 100\%; 95\% CI: 78.2-100\%; positive predictive value: $100 \%)$. As shown in Fig. 2 c, we observed a strong positive relationship between $\mathrm{HCV}$ cAg levels measured in DBS specimens and serum HCV RNA level ( $r=0.80$; $P<0.0001)$, regardless of the HCV genotype. Among the $11 \mathrm{~dB}$ samples collected from patient with chronic $\mathrm{HCV}$ infection but tested negative for HCVcAg on DBS, serum HCV-RNA viral load ranged from 711 to 88,600 IU/mL (median: $29300 \mathrm{IU} / \mathrm{mL}$; IQR: 23,800 to 36,900 $\mathrm{IU} / \mathrm{mL}$ ). Of these samples tested negative for $\mathrm{HCVcAg}$ on DBS specimen but positive for serum HCV RNA, seven were positive for HCV RNA on DBS. By

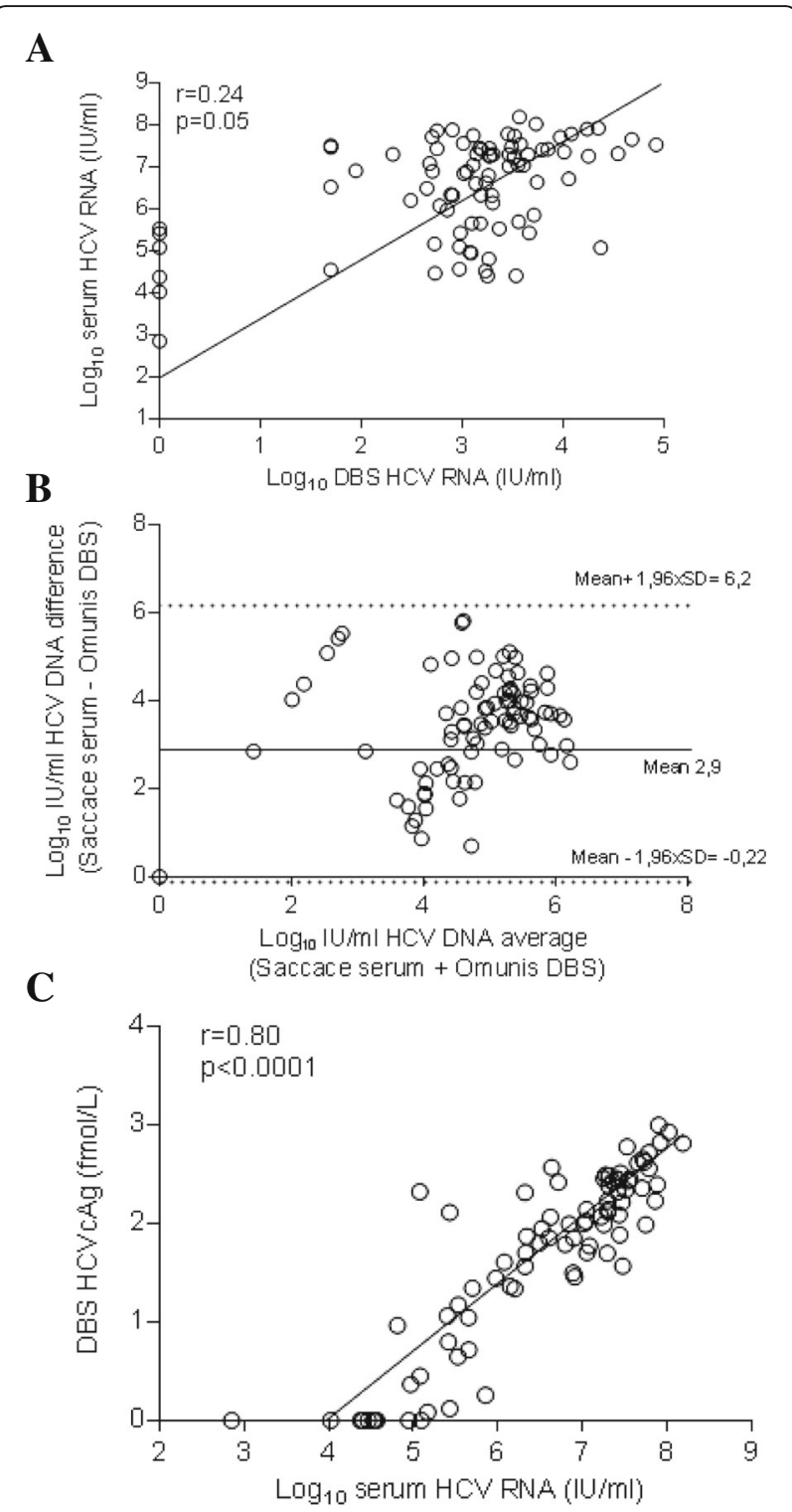

Fig. 2 Assessment of HCV RNA and HCVCAg on DBS specimens collected from HIV/HCV co-infected patients care in Haiphong Viet Tiep Hospital, Vietnam. a Linear regression analysis HCV RNA levels for 86 matched DBS-serum pairs collected from subjects with chronic HCV infection. b Agreement between the HCV RNA quantification by plotting the differences between serum and DBS specimen averages of the two techniques using the Bland-Altman analysis. c Correlation between DBS HCVCAg and serum HCV RNA

comparison, four DBS samples not tested negative for $\mathrm{HCV}$ RNA were found reactive for $\mathrm{HCV}$ cAg. A good agreement was observed between the HCV RNA and the HCVcAg Ag tests performed on DBS (Kappa coefficient: 0.65 ) in Table 2.

\section{Discussion}

Research evaluations are needed regarding novel laboratory techniques that would allow confirmation of $\mathrm{HCV}$ 
Table 2 Clinical performance and agreement of HCV RNA and HCVCAg detection on DBS

\begin{tabular}{lccc}
\hline & Specificity \% $(\mathrm{n})$ & Sensitivity \% $(\mathrm{n} ; 95 \% \mathrm{Cl})$ & Cohen coefficient \\
\hline DBS HCV RNA & $100 \%(15 / 15)$ & $92.0 \%(79 / 86 ; 86.3-97.7)$ & $87.2 \%(75 / 86 ; 79.9-94.1)$ \\
DBS HCVCAg & $100 \%(15 / 15)$ & & 0.65 \\
HCV RNA/HCVCAg agreement & & & \\
\hline
\end{tabular}

replication without the need for expensive laboratory equipment or trained personnel at the site of blood collection. Testing the feasibility, diagnostic accuracy, cost-effectiveness and clinical impact of $\mathrm{HCVcAg}$ or HCV RNA assays on DBS in field conditions remain some of the research gaps. In this study, the detection of HCV RNA using an open polyvalent PCR platform, and the detection of $\mathrm{HCV}$ core antigen on DBS confirmed the HCV replication in almost 9 out of 10 patients with chronic HCV infection. The nucleic acid tests on DBS provided a better sensitivity than the detection of $\mathrm{HCV} c \mathrm{Ag}$, however, the HCVcAg antigen test on DBS appears to benefit from substantial stability under prolonged storage conditions.

$\mathrm{HCV}$ cAg detection may contribute to improve an access to $\mathrm{HCV}$ diagnosis in low- and middle-income countries. Blood collection on DBS, make possible to combine decentralized capillary blood collection with simple transportation from remote areas to regional laboratories [15]. Based on a systematic reviews and evidence summaries of the of the primary literature, recommendation was made by WHO to consider the use of DBS specimens as an option to facilitate an access to $\mathrm{HCV}$ antibodies and nucleic acid testing [16]. Good performance of nucleic acid tests on DBS have been reported for HCV RNA detection, with an overall sensitivity and specificity estimated to $96.0 \%$ (95\% CI: 93.4-97.6\%) and 97.7\% (95\% CI: 94.7-99.0\%), respectively [17]. In this study we have concomitantly evaluated HCV RNA and HCVcAg on DBS in HIV/HCV co-infected people living in Vietnam. The sensitivity for HCV RNA detection on DBS collected in Vietnam were seated around the lower limit of the lower bounds values reported in previous studies [17]. Some samples with high serum HCV viremia were found undetectable for HCV RNA on DBS collected in Vietnam and we observed a low correlation for HCV RNA values between DBS and serum specimens. These DBS samples collected from the Hanoi Hospital were transported to France at ambient temperature, undertaken frozen-thawed cycles and were stored during a prolonged period. Thus, a partial degradation of HCV RNA can be suspected. DBS specimens are considered as generally stable over time, maintaining good accuracy in tropical conditions. However, degradation of RNA on DBS has been reported suggesting that $\mathrm{HCV}$ RNA levels can decrease over the prolonged transportation, long term storage at ambient temperature and freeze-thaw cycles [15, 19-21]. Our results confirm that assessment and control of the pre-analytical conditions remains critical for the accurate quantification of HCV RNA on DBS. In line with previous studies, we observed a high positive predictive value using HCVcAg detection on DBS $[13,18]$ showing that the assay is highly performing to confirm $\mathrm{HCV}$ replication. Laboratory performances of $\mathrm{HCV} \mathrm{CAg}$ testing on DBS have been evaluated by Soulier et al. [13] but evaluation should be done in the field, in low-resource countries. High rate of $\mathrm{HCV}$ cAg detection on DBS was recently reported in $\mathrm{HCV}$ infected peoples who inject drugs in Tanzania, suggesting that HCVcAg on DBS may be an alternative to serum HCV PCR [18]. HCVcAg quantitation performed after 18 months of DBS collection was remarkably well correlated to serum HCV RNA level. This good correlation is in line with previous reports using serum specimens [20, 22], or DBS [13, 18] for HCVcAg quantitation. This observation suggests that HCVcAg is less susceptible to degradation than HCV RNA under the undesirable storage and transportation conditions that the DBS collected in our study underwent. HCVcAg detection on DBS can be a simple and useful alternative method to confirm $\mathrm{HCV}$ replication but the limit of serum HCVcAg detection estimated to about $3000 \mathrm{UI} /$ mL HCV RNA $[14,22]$ is lower than serum HCV RNA assays. Furthermore, it is substantially reduced compared to the LOD of DBS HCV RNA.. Hence, the LOD of HCVcAg can be estimated equivalent around $10^{5} \mathrm{IU} / \mathrm{mL}$ HCV RNA $[13,18]$. In our study all serum samples tested negative for HCVcAg on paired DBS have HCV RNA level below $10^{5}$ $\mathrm{IU} / \mathrm{mL}$. Even with such suboptimal sensitivity, the detection $\mathrm{HCV}$ cAg on DBS is able to confirm HCV replication in the majority of seropositive patients since the HCV RNA level is generally higher than $10^{5} \mathrm{IU} / \mathrm{mL}$ during the chronic HCV infection [23, 24]. Diagnostic algorithm based on $\mathrm{HCVcAg}$ detection has been proposed to directly identify chronic HCV infection [7, 18]. Predictive negative values over 90\% [14] in blood but below 60\% on DBS $[13,18]$ have been reported suggesting that the performances of HCVcAg testing may be insufficient as a one-step HCV screening and confirmation test when DBS are used. Furthermore, the HCVcAg test performed on the Abbott Architect platform is the only assay extensively studied and widely available [14]. The characteristics of this automated laboratory apparatus limit the access to this marker to well-equipped laboratories. No $\mathrm{HCVcAg}$ point of care tests are currently available to confirm HCV replication in subjects tested positive for $\mathrm{HCV}$ antibodies. 
In conclusion, the quantification of HCVcAg on DBS appears to benefit from substantial stability under prolonged storage conditions but with a higher LOD than for HCV RNA on DBS. Detection of HCV RNA on DBS is an efficient approach for confirming viral replication in $\mathrm{HCV}$ seropositive individuals but should be accompanied by an assessment of the pre-analytical conditions observed during the transportation and HCV RNA preservation before the tests. Although the lack of qualification of the HCV tests on DBS specimens, and the absence of technological solutions adapted to resource-limited countries for $\mathrm{HCV}$ cAg testing are important limitations, one of the most feasible and cost-effective strategy to confirm HCV replication in many countries may be the collection of DBS for testing HCV RNA or HCVcAg in central locations.

\section{Conclusions}

Quantification of $\mathrm{HCVcAg}$ on DBS appears to benefit from substantial stability under prolonged storage conditions but with a lower analytical sensitivity compared to DBS HCV RNA testing. Detection of HCV RNA on DBS is an interesting approach for confirming viral replication in $\mathrm{HCV}$ seropositive persons but the impact of pre-analytical conditions on the integrity of HCV RNA needs to be controlled.

\begin{abstract}
Abbreviations
ANRS: France REcherche Nord\&Sud Sida-hiv Hépatites; DBS: Dried Blood Spot; HCV RNA: hepatitis C virus ribonucleic acid; HCVcAg: Hepatitis C virus core antigen; HIV: Human immunodeficiency virus; PCR: Polymerase chain reaction; RNA: Ribonucleic acid; WHO: World Health Organization
\end{abstract}

\section{Acknowledgements}

This work was supported by a doctoral scholarships awarded to TTN by the Ambassy of France in Vietnam. The authors thank the participants and the team of the HIV outpatient clinic working at the Viet Tiep Hospital in Haiphong.

\section{Funding}

This study formed part of a grant from the French National Agency for Research on AIDS and Viral Hepatitis [ANRS 12336].

\section{Availability of data and materials}

The datasets generated and analysed during the current study are not publicly available due we don't want share our dataset, but are available from the corresponding author on request.

\section{Authors' contributions \\ TTN and ET designed the study; $K L, T T N, M L$ and ET performed statistical analysis and drafted the first version of this manuscript; VL, KB, JCP, CD and ET carried out the virological studies; TTN, DL, HW, QAL, XLTT and HDT collected sample and the demographic data. All other authors read and approved the final manuscript.}

\section{Ethics approval and consent to participate}

The study protocol and written informed consent form were approved by the Ethic Committee of the Viet Tiep Hospital and the Institutional Review Board (IRB) of the Haiphong Medical Services ( $n^{\circ}$ 01BWT/HDKH). Then, the written informed consent was obtained from all participants before blood sampling. Privacy and confidentiality as well as the anonymity of the participants were ensured at all stages of data collection.

\section{Consent for publication}

Not applicable.

\section{Competing interests}

The authors declare that they have no competing interests.

\section{Publisher's Note}

Springer Nature remains neutral with regard to jurisdictional claims in published maps and institutional affiliations.

\section{Author details}

${ }^{1}$ University of Medicine Pham Ngoc Thach, Ho Chi Minh City, Vietnam. ${ }^{2}$ Pathogenesis and Control of Chronic Infections, INSERM, Université de Montpellier, CHU Montpellier, Montpellier, France. ${ }^{3}$ Normandie Univ., CHU Rouen, Laboratoire de Virologie, Rouen, France. ${ }^{4}$ Department of Infectious and Tropical Diseases, Viet Tiep Hospital, Hai Phong, Vietnam. ${ }^{5}$ Department of Infectious and Tropical Diseases, Saint-Antoine Hospital, AP-HP, Sorbonne Universités, Université Paris 06, INSERM S 1136, iPLESP, Paris, France. ${ }^{6}$ Pasteur Institute, Ho Chi Minh City, Vietnam. 'Department of Public Health, University of Medicine and Pharmacy, Hai Phong, Vietnam. ${ }^{8}$ Pathogenesis and Control of Chronic Infections, INSERM, Université de Montpellier, CHU Nîmes, Montpellier, France. ${ }^{9}$ Department of Hepatology, St Mary's Hospital, Imperial College, London, UK.

Received: 11 May 2018 Accepted: 19 November 2018 Published online: 04 December 2018

\section{References}

1. Easterbrook PJ, WHO guidelines development group. WHO to test and how to test for chronic hepatitis C infection - 2016 WHO testing guidance for low- and middle-income countries. J Hepatol. 2016;65(1 Suppl):S46-66.

2. WHO. Combating hepatitis B and C to reach elimination by 2030. 2016. Available at http://www.who.int/hepatitis/publications/hep-elimination-by2030-brief/en/

3. Polaris Observatory HCV Collaborators. The global burden of viral hepatitis from 1990 to 2013: findings from the Global Burden of Disease Study 2013. Lancet. 2016; 388(10049):1081-88.

4. WHO. Global health sector strategy on viral hepatitis, 2016-2021. Available from: http://www.who.int/hepatitis/strategy2016-2021.

5. WHO. Guidelines on Heaptitis B and C Testing 2017. Available from: http:// apps.who.int/iris/bitstream/10665/254621/1/9789241549981-eng. Accessed 6 Feb 2017.

6. WHO Prequalification of In Vitro Diagnostics PUBLIC REPORT Product: OraQuick HCV Rapid Antibody Test Kit WHO reference number: PQDx 0244 055-00. Available from: http://www.who.int/diagnostics_laboratory/ evaluations/pq-list/hcv/170301_final_pq_report_PQDx_0244_055_00.pdf. Accessed 1 Mar 2017.

7. Duchesne L, Njouom R, Lissock F, Tamko-Mella GF, Rallier S, Poiteau L, Soulier A, Chevaliez S, Vernet G, Rouveau N, Pawlotsky JM, Girard PM, Lacombe K. HCV Ag quantification as a one-step procedure in diagnosing chronic hepatitis C infection in Cameroon: the ANRS 12336 study. J Int AIDS Soc. 2017;20(1):21446.

8. Berto A, Day J, Van Vinh Chau N, Thwaites GE, My NN, Baker S, Darton TC. Current challenges and possible solutions to improve access to care and treatment for hepatitis C infection in Vietnam: a systematic review. BMC Infect Dis. 2017;17(1):260. https://doi.org/10.1186/s12879-017-2360-6.

9. Duong HT, Jarlais DD, Khuat OHT, Arasteh K, Feelemyer J, Khue PM, Giang HT, Laureillard D, Hai W, Vallo R, Michel L, Moles JP, Nagot N. Drive study group. Risk behaviors for HIV and HCV infection among people who inject drugs in Hai Phong, Viet Nam, 2014. AIDS Behav. 2017. https://doi.org/10. 1007/s10461-017-1814-6.

10. Ministry of Health. Plan of preventing viral Hepatits Deseases in Vietnam 2015-2019. 2015. Information on: http://www.wpro.who.int/vietnam/ mediacentre/releases/2015/worldhepatitisday2015/en/

11. Nguyen Truong T, Laureillard D, Lacombe K, Duong Thi H, Pham Thi Hanh P, Truong Thi Xuan L, Chu Thi N, Luong Que A, Vu Hai V, Nagot N, Tuaillon E, Dominguez S, Lemoine M. High proportion of HIV-HCV Coinfected patients with advanced liver fibrosis requiring hepatitis $C$ treatment in Haiphong, northern Vietnam (ANRS 12262). PLoS One. 2016;11(5):e0153744.

12. Flahault A, Cadilhac M, Thomas G. Sample size calculation should be performed for design accuracy in diagnostic test studies. J Clin Epidemiol. 2005;58(8):859-62.

13. Soulier A, Poiteau L, Rosa I, Hézode C, Roudot-Thoraval F, Pawlotsky JM, Chevaliez S. Dried blood spots: a tool to ensure broad access to hepatitis C 
screening, diagnosis, and treatment monitoring. J Infect Dis. 2016;213(7): 1087-95.

14. Freiman JM, Tran TM, Schumacher SG, White LF, Ongarello S, Cohn J, Easterbrook PJ, Linas BP, Denkinger CM. Hepatitis C Core antigen testing for diagnosis of hepatitis $C$ virus infection: a systematic review and metaanalysis. Ann Intern Med. 2016;165(5):345-55.

15. Tuaillon E, Montain A, Meroueh F, Ottomani L, Picot MC, Nagot N, et al. Dried blood spot for hepatitis $C$ virus serology and molecular testing. Hepatology. 2010;51(3):752-8.

16. Lange B, Cohn J, Roberts T, Camp J, Chauffour J, Gummadi N, Ishizaki A, Nagarathnam A, Tuaillon E, van de Perre P, Pichler C, Easterbrook P, Denkinger CM. Diagnostic accuracy of serological diagnosis of hepatitis $C$ and B using dried blood spot samples (DBS): two systematic reviews and meta-analyses. BMC Infect Dis. 2017;17(Suppl 1):700.

17. Lange B, Roberts T, Cohn J, Greenman J, Camp J, Ishizaki A, Messac L, Tuaillon E, van de Perre P, Pichler C, Denkinger CM, Easterbrook P. Diagnostic accuracy of detection and quantification of HBV-DNA and HCVRNA using dried blood spot (DBS) samples - a systematic review and metaanalysis. BMC Infect Dis. 2017;17(Suppl 1):693.

18. Mohamed Z, Mbwambo J, Shimakawa Y, Poiteau L, Chevaliez S, Pawlotsky JM, Rwegasha J, Bhagani S, Taylor-Robinson SD, Makani J, Thursz MR, Lemoine M. Clinical utility of HCV core antigen detection and quantification using serum samples and dried blood spots in people who inject drugs in Dar-es-salaam, Tanzania. J Int AIDS Soc. 2017;20(1):21856.

19. Abe K, Konomi N. Hepatitis C virus RNA in dried serum spotted onto filter paper is stable at room temperature. J Clin Microbiol. 1998;36(10):3070-2.

20. J G, Roberts T, Cohn J, Messac L. Dried blood spot in the genotyping, quantification and storage of HCV RNA: a systematic literature review. J Viral Hepat. 2015;22(4):353-61.

21. Mederacke I, Wedemeyer H, Ciesek S, Steinmann E, Raupach R, Wursthorn K, Manns MP, Tillmann HL. Performance and clinical utility of a novel fully automated quantitative HCV-core antigen assay. J Clin Virol. 2009;46(3):210-5.

22. Descamps V, Op de Beeck A, Plassart C, Brochot E, François C, Helle F, Adler M, Bourgeois N, Degré D, Duverlie G, Castelain S. Strong correlation between liver and serum levels of hepatitis $C$ virus core antigen and RNA in chronically infected patients. J Clin Microbiol. 2012;50(2):465-8.

23. Ottiger C, Gygli N, Huber AR. Detection limit of architect hepatitis C core antigen assay in correlation with HCV RNA, and renewed confirmation algorithm for reactive anti-HCV samples. J Clin Virol. 2013;58(3):535-40.

24. Ticehurst JR, Hamzeh FM, Thomas DL. Factors affecting serum concentrations of hepatitis C virus (HCV) RNA in HCV genotype 1-infected patients with chronic hepatitis. J Clin Microbiol. 2007;45(8):2426-33.

Ready to submit your research? Choose BMC and benefit from:

- fast, convenient online submission

- thorough peer review by experienced researchers in your field

- rapid publication on acceptance

- support for research data, including large and complex data types

- gold Open Access which fosters wider collaboration and increased citations

- maximum visibility for your research: over $100 \mathrm{M}$ website views per year

At $\mathrm{BMC}$, research is always in progress.

Learn more biomedcentral.com/submissions 